\title{
Oswald and the Strong Man Armed
}

\author{
Julia Barrow
}

Barbara Yorke has made major contributions to our understanding of early Anglo-Saxon kingdoms, including Northumbria, and this paper, which aims to shed some new light on Bede's handling of one of the key battles in early Northumbrian history, is presented to her as a small thank-offering for her work in this field and for her many kindnesses to fellow-scholars. ${ }^{1}$ Most recently Barbara Yorke has turned her attention to Aldfrith of Northumbria and his associations with Iona and Abbot Adomnán before the latter helped him to become king of Northumbria following the death of his half-brother Ecgfrith in $685 .{ }^{2}$ This paper goes a little further back in time to look at Aldfrith's uncle Oswald, another Northumbrian ruler with strong Ionan connections, and in particular at Bede's account of how Oswald defeated Caedwalla, king of the Britons, near Hexham in 634. As has long been noted by commentators, Bede does not provide any practical military information about the battle but instead concentrates on its spiritual meanings, and this paper will attempt to explore some of these further. ${ }^{3}$ The main aim is to point out a hitherto unnoticed set of allusions to passages in Luke Ch. 11 and Matthew Ch. 12 in the two opening chapters of Book III of Bede's Ecclesiastical History: paying attention to these allows us to see how Bede shaped his material, ${ }^{4}$ and in particular helps to deepen discussion of three debates about Bede's $H E$, first of all his presentation of the kingdom of Northumbria as united polity, secondly whether or not he had read Adomnán's Life of St Columba and thirdly why he describes Oswald

1 See esp. Barbara Yorke, Kings and Kingdoms of Early Anglo-Saxon England (London, 1990), pp. 72-99, and The Conversion of Britain 6oo-80o (Harlow, 2006), passim, and items in following note.

2 Barbara Yorke, Rex Doctissimus: Bede and King Aldfrith of Northumbria, Jarrow Lecture, 2009 (Jarrow, 2009); "Adomnán at the Court of King Aldfrith," in Adomnán of Iona: Theologian, Lawmaker, Peacemaker, ed. Jonathan Wooding and Rodney Aist (Dublin, 2010), pp. 36-50.

3 See, for example, Clare Stancliffe, "Oswald, 'Most Holy and Most Victorious King of the Northumbrians," in Oswald: Northumbrian King to European Saint, ed. Clare Stancliffe and Eric Cambridge (Stamford, 1995), pp. 44-45; N.J. Higham, The Convert Kings: Power and Religious Affiliation in Early Anglo-Saxon England (Manchester, 1997), pp. 33-83, at pp. 206-07; N.J. Higham, Ecgfrith, King of the Northumbrians, High King of Britain (Donington, 2015), p. 67.

4 For discussion of some of the issues leading Bede to shape his material as he did, see Stancliffe, "Oswald, 'most holy and most victorious king of the Northumbrians'." 
as raising "the sign of the cross" at Heavenfield next to the Roman Wall before setting out to fight his adversary. ${ }^{5}$ This paper looks at the events following Edwin's death and Bede's use of biblical exegesis to provide a framework for his account of these, and then at Oswald's activities at Heavenfield and how Adomnán and Bede diverged in their interpretations of them.

The origins of the battle between Oswald and Caedwalla lay in the latter's victory over Edwin of Northumbria at the battle of Hatfield Chase in 633, a significant defeat for the Northumbrian Angles in which Edwin and one of his sons, Osfrith, were killed. ${ }^{6}$ Caedwalla was given support on this occasion by Penda, a member of the Mercian royal family who from this point became king of the Mercians, ${ }^{7}$ but it is likely that this alliance was brief, as Penda allowed another of Edwin's sons, Eadfrith, to take refuge with him. ${ }^{8}$ The Caedwalla who killed Edwin and was in turn killed by Oswald was identified in the early gthcentury Historia Brittonum as Cadwallon son of Cadfan, king of Gwynedd; ${ }^{9}$ this identification has recently been questioned by Alex Woolf, who suggested that he is more likely to have been a king of a British kingdom in northern England, possibly Elmet, but Woolf's interpretation has met with mixed responses. ${ }^{10}$ The earliest sources to mention Caedwalla, Adomnán's Life of Columba, written in the 69os, followed in 731 by Bede's $H E$, refer to him only as "king of the

Recourse is made in this article at different points to three editions of Bede's Ecclesiastical History (in general cited below as $H E$ with book and chapter number): Venerabilis Baedae Opera Historica, ed. Charles Plummer, 2 vols (Oxford, 1896); Bede, Historia Ecclesiastica in Bede's Ecclesiastical History of the English People, ed. Bertram Colgrave and R.A.B. Mynors (Oxford, 1969); Bède le Vénérable, Histoire ecclésiastique du peuple anglais, ed. André Crépin, Michael Lapidge, Pierre Monat and Philippe Robin, 3 vols, Sources chrétiennes 489-91 (Paris, 2005); for Adomnán see Adomnan's Life of Columba, ed. and trans. Alan Orr Anderson and Marjorie Ogilvie Anderson, rev. by Marjorie Ogilvie Anderson (Oxford, 1991) and Adomnán of Iona, Life of St Columba, trans. Richard Sharpe (Harmondsworth, 1995).

$6 \quad H E$ II.20.

7 For discussion of Penda see Nicholas Brooks, "The Formation of the Mercian Kingdom," in The Origins of Anglo-Saxon Kingdoms, ed. Steven Bassett (Leicester, 1989), pp. 158-70, esp. 164-70; repr. in Anglo-Saxon Myths: State and Church 400-1066 (London, 2000), pp. 61-77, at pp. $69-77$.

$8 \quad H E$ II.20; see also discussion by Alex Woolf, "Caedualla Rex Brettonum and the Passing of the Old North," Northern History 41 (2004), 5-24 at pp. 7-8.

9 Nennius, British History and the Welsh Annals, ed. and trans. John Morris (Chichester, 1980), pp. 78-79.

10 Woolf, "Caedualla Rex Brettonum," followed by Yorke, Conversion of Britain, p. 63 and James E. Fraser, From Caledonia to Pictland: Scotland to 795 (Edinburgh, 2009), pp. 166-67, but not by T.M. Charles-Edwards, Wales and the Britons 350-1064 (Oxford, 2013), p. 358, and specifically rejected by John T. Koch, Cunedda, Cynan, Cadwallon, Cynddylan: Four Welsh Poems and Britain, 383-655 (Aberystwyth, 2013), pp. 163-85. 
Britons." ${ }^{\prime 1}$ In Bede's account, the area especially ravaged by Caedwalla 633-34 seems to have been the territory around Cambodunum (perhaps modern Leeds) ${ }^{12}$ since in $H E$ II.14 it is stated that the heathen who killed Edwin burned down the royal vill and church there; it is worth noting that the stone altar from the church was removed to the monastery of the priest-abbot Thrythwulf in the forest of Elmet. Given the site of Oswald's eve-of-battle camp at Heavenfield, just on the northern side of the Roman Wall and thus protected against attacks from the south, and within about four miles of Dere Street (the A68), it seems likely that the enemy they faced was advancing from the south, perhaps along Dere Street. ${ }^{13}$ Caedwalla's most recently recorded activity before meeting Oswald was his killing of Eanfrith, presumably somewhere in Bernicia, but since he appears to have remained on the move in Northumbria (HE II.20: "for a long time raged through all their land") we cannot be sure of his itinerary.

On Edwin's death, Caedwalla was not powerful enough to take over the areas Edwin had ruled or to prevent the succession of Anglian rulers in Northumbria; equally, the Northumbrian Angles could not agree on a single successor. Edwin's nephew Osric was established as king in his uncle's heartland, Deira, while the Bernicians chose Eanfrith, one of the sons of Æthelfrith, the Bernician dynast who had been king of Northumbria 604-16 (king in Bernicia 592-616) and who had been Edwin's great enemy. ${ }^{14}$ Both Osric and Eanfrith apostasised, abandoning their Christian profession for paganism: "Qui uterque rex, ut terreni regni infulas sortitus est, sacramenta regni caelestis, quibus initiatus erat, anathematizando prodidit, ac se priscis idolatriae sordidibus polluendum perdendumque restituit."15 Bede probably saw the apostasy as

11 For the dating of the Life of St Columba see Adomnán, Life of St Columba, ed. Sharpe, p. 55.

12 A.L.F. Rivet and Colin Smith, The Place-Names of Roman Britain (London, 1979), p. 293.

13 Heavenfield is just to the north of the Roman Wall, lying a mile and a half east of Chollerford, a strategic ford over the North Tyne, and about 4 miles west of where Dere Street crosses the wall. Colgrave and Mynors' translation (p. 217), places Heavenfield south of the Roman Wall: "This place, on its north side, is close to the wall," but Bede's "Est autem locus iuxta murum illum ad aquilonem" should be "Now this place is next to the wall to the north." On the site see Eric Cambridge, "Archaeology and the Cult of St Oswald in preConquest Northumbria," in Oswald: Northumbrian King to European Saint, ed. Stancliffe and Cambridge, pp. 140, 163; Alison Binns, "Pre-Reformation Dedications to St Oswald in England and Scotland: A Gazetteer," in Stancliffe and Cambridge, p. 255. For a picture of the site see N.J. Higham, The Kingdom of Northumbria AD 350-110o (Stroud, 1993), p. 125.

14 Colgrave and Mynors, pp. 212 (HE III.1 on Osric and Eadfrith); see Colgrave and Mynors, pp. 116, 176-80 (HE I.34 and II.12 on Æthelfrith).

$15 H E$ III.1: "But no sooner had these two kings gained the sceptres of their earthly kingdom than they abjured and betrayed the mysteries of the heavenly kingdom to which they had been admitted and reverted to the filth of their former idolatry, thereby to be polluted and destroyed" (Colgrave and Mynors' translation, p. 213). 
symbolically linked to the division of the kingdom, as we will see. He presents the establishment of the two kings as the division of what had been a single people and kingdom, for, down to his statement in $H E$ III.1, that the people (gens) of the Northumbrians consisted of the regnum Deirorum and the regnum Berniciorum, he always depicts the Northumbrians as unified. This is the case when he introduces Æthelfrith in $H E$ I.34 ("regno Nordanhymbrorum"), ${ }^{16}$ when he describes Edwin's powers in $H E$ II.9 ("gens Nordanhymbrorum, hoc est ea natio Anglorum, quae ad Aquilonalem Humbre fluminis plagam habitabat" $)^{17}$ and indeed also in his mention of Ida in his chronological summary in $H E$ V.24, under the year 547 ("Ida regnare coepit, a quo regalis Nordanhymbrorum prosapia originem tenet ..."). ${ }^{18}$ Historians have for nearly a century noted that Bede's unified presentation of the Northumbrians cannot be accepted as it stands, ${ }^{19}$ and have also explored how far Bede himself was responsible for originating or at any rate popularising the term "Northumbrians," 20 but there is in addition a religious significance to Bede's reluctance to name the Deirans and the Bernicians earlier than in $H E$ III.1. The admission that the people of the Northumbrians had anciently been divided into two provinces ("nam in has duas provincias gens Nordanhymbrorum antiquitus divisa erat") allowed Bede to compare Northumbria with the kingdom divided against itself that cannot stand in Luke 11:17, Matthew 12:25 and Mark 3:24.

16 Colgrave and Mynors, p. 116 (I.34): "the kingdom of Northumbria," though more literally "the kingdom of the Northumbrians."

17 Colgrave and Mynors, p. 162 (II.9): "the Northumbrian race, that is the English race which dealt north of the river Humber."

18 Colgrave and Mynors, p. 562 (v.24: "Ida began to reign, from whom the Northumbrian royal family trace their origin").

19 J.N.L. Myres, "The Teutonic Settlement of Northern England," History 20 (1935), 250-62; Peter Hunter Blair, "The Boundary between Bernicia and Deira," Archaeologia Aeliana, 4th ser., 27 (1949), 46-59, esp. p. 51, sees the division as deriving from separate groups of English settlers; J.M. Wallace Hadrill, Bede's Ecclesiastical History of the English People: A Historical Commentary (Oxford, 1988), pp. 87, 97. However, Ian Wood has recently argued for a unified northern polity across the area from the Roman Wall to Yorkshire in the subRoman period that subsequently was divided into the tribal groups of the Bernicians and the Deirans, headed by descendants of continental settlers brought in by the Romans as military forces: "The Roman Origins of the Northumbrian Kingdom," in Italy and Early Medieval Europe, ed. Ross Balzaretti, Julia Barrow and Patricia Skinner (Oxford, 2018), pp. 39-49.

20 Myres, "The Teutonic Settlement"; Peter Hunter Blair, "The Northumbrians and their Southern Frontier," Archaeologia Aeliana, 4th ser., 26 (1948), 98-126, at p. 104; T.M. CharlesEdwards, "Bede, the Irish and the Britons," Celtica 15 (1983), 42-52, esp. pp. 49-5o; see also Yorke, Kings and Kingdoms, p. 74. 
In Luke and Matthew's gospels, Christ's statement "A kingdom divided against itself shall not stand" comes immediately after he had been presented with a dilemma, on the one hand being pestered for healing cures but on the other facing criticism for carrying these out on the Sabbath. Some of his audience was hungry to see signs of God's presence while others were accusing him of casting out devils in the name of Beelzebub rather than in the name of God. ${ }^{21}$ In response to this latter group Christ stated that Satan cannot be divided against himself but is a strong man armed who takes over a house, as a metaphor for demons taking possession of a human being. ${ }^{22}$ All of this supplied Bede with imagery. In his portrayal, the apostate kings, Osric and Eanfrith, are evidently not types of Satan (their division prevents this) but creatures taken over by him. In his commentary on Luke 11:17 Bede had compared the undivided kingdom to the Trinity standing up against the heresy of the Arians, who thought the Son was lesser than the Father and the Spirit was lesser than the Son; presumably Osric and Eanfrith, kings of a divided kingdom, were comparable to heretics. ${ }^{23}$ Their failure to maintain their Christian faith and their inability to join together had left Northumbria vulnerable to attack by a Satanic figure, Caedwalla, who, although "he had the name and profession of a Christian," was a barbarian in outlook and behaviour who did not spare women or children and who tortured and murdered his victims. ${ }^{24}$ Caedwalla, moreover, wandered through the Northumbrian provinces for a long time ( $H E$ II.20), resembling Satan in his wanderings as depicted in Job 2:2, in 1 Peter 5:8 and especially in Luke 11:24 where the exorcised devil is said to wander through dry places, which Bede in his commentary on Luke explains as schismatics and bad Catholics. ${ }^{25}$ An even more explicit connection between Caedwalla and

21 In his commentary on Luke, Bede argued for the reading Beelzebub against Beelzebul (Luke 11: 18): see Bede, Opera exegetica, 3: In Lucae evangelium expositio; in Marci evangelium expositio, ed. D. Hurst, CCSL 120 (Turnhout, 1960), p. 232 (IV.xi.15).

22 For the "strong man armed" see Luke 11:21, and for Bede's comment on the phrase (he defined "the strong man armed" as the devil) see In Lucae evangelium expositio, p. 234 (IV.xi. 21).

23 Bede, In Lucae evangelium expositio, p. 232 (IV.xi.17; for Bede's discussion of the passage as a whole see pp. 232-34).

$24 H E$ II.20. Bede did not portray Caedwalla "by implication, as a pagan" (pace Fred Orton and Ian Wood with Clare A. Lees, Fragments of History: Rethinking the Ruthwell and Bewcastle Monuments (Manchester, 2007), p. 171); he was accusing Caedwalla of something much worse. For discussion of Bede's use of 'barbarian' here see Clare Stancliffe, Bede and the Britons (Whithorn, 2007), pp. 19-22.

25 HE II.20 (Colgrave and Mynors, pp. 202-04) for Caedwalla moving about; Bede, In Lucae evangelium expositio, pp. 234-35 (IV.xi.24). 
Satan in Bede's mind can be found in his application of the term "outrageous tyranny" to Caedwalla ("vesanam Brittonici regis tyrannidem"), which parallels his phrase "vesaniam suae tyrannidis" ("the madness of his tyranny") for the devil's power over the minds of the faithless in his commentary on Mark 11:22$23 .{ }^{26}$ One of the influences behind Bede's use of the word tyrant may have been Rufinus, the translator of Eusebius' Ecclesiastical History; Rufinus associated the terms 'barbarian' and 'pagan' with the term 'tyrant', and it is noticeable that Bede brings both of these into play in his description of Penda and Caedwalla in $H E$ II.20, describing Penda as a pagan and Caedwalla as a barbarian more savage than a pagan. ${ }^{27}$

Christ said that Satan, the strong man armed, could only be dislodged from his house if someone stronger than he attacked him. Osric's attempt to besiege Caedwalla, who had taken refuge in a fortified town ("in oppido municipio") $)^{28}$ failed because Caedwalla was able to make a surprise sortie and kill him. Eanfrith, even weaker, tried to make terms with Caedwalla and was killed. ${ }^{29}$ Clearly neither Osric nor Eanfrith was the stronger man capable of defeating the strong man armed (Luke 11: 21-22): as Bede would have seen it, their lack of Christian faith would have precluded this. The stronger man was about to

$26 \quad H E$ III.1 (Colgrave and Mynors, p. 214) for Caedwalla's outrageous tyranny (note also Bede's reference to him in III.1 as "tyrannus saeviens," "a savage tyrant," Colgrave and Mynors, p. 212); Bede, In Marci Evangelium Expositio, p. $5^{81}$ (III.xi.22-23). Similar links between the devil and tyranny in Bede's writings can be found in $H E$ IV.14 ("the tyranny of the devil" referring to the state of paganism among the South Saxons), and Bede's Prose Life of Cuthbert, Ch. 17, for Cuthbert overcoming an army of tyrants by fighting against demons while a hermit on Farne (Two Lives of St Cuthbert, ed. and trans. Bertram Colgrave (Cambridge, 1940), p. 214). Charles-Edwards, "Bede, the Irish and the Britons," p. 46, contrasts the tyranny of Caedwalla with the imperium of Edwin and Oswald.

$27 H E$ iI.20: Colgrave and Mynors, p. 202. On Rufinus' use of the word tyrannus in association with barbari and pagani, see J.M. Wallace-Hadrill, Bede's Ecclesiastical History of the English People: a Historical Commentary (Oxford, 1988), p. 89.

28 Plummer, in his edition of $H E$ II.121, followed by Colgrave and Mynors (p. 213), and Crépin (vol. 2, p. 17, n. 4), identifies this as York, but Woolf, "Caedualla," pp. 7-8 argues against this because Bede always refers to York as a civitas. Glanville Jones, "Multiple Estates and Early Settlement," in Medieval Settlement: Continuity and Change, ed. P.H. Sawyer (London, 1976), pp. 15-40, at p. 38, suggested Aldborough (Isurium), a Roman municipium at a strategic site on Dere Street, at this point heading NW from York and just to the north of its junction with a road coming north from Tadcaster (for Aldborough's communications see Ivan D. Margary, Roman Roads in Britain, rev. edn (London, 1967), pp. 359, 407, 428); James Campbell, "Bede's Words for Places," reprinted in his Essays in Anglo-Saxon History (London, 1986), p. 103, proposed that oppidum municipium "is a Latin version of the Cair Mincip (Mencipit), which occurs in the Nennian list of twenty-eight civitates."

$29 H E$ III..1; on Bede's use of the term 'damnavit' ('condemned'?) for Caedwalla's treatment of Eanfrith, suggesting a form of execution, see Woolf, "Caedualla," p. 7. 
appear, however, in the form of Eanfrith's brother Oswald, who led a smaller army ("but strengthened in faith": sed fide Christi munito) to victory against Caedwalla in spite of the latter's "immense forces, which he boasted nothing could resist" (HE III.1). Oswald is evidently being portrayed as a type of Christ here. Bede also treats Oswald in this way in $H E$ IV.14, where he is credited with saving inmates of a South Saxon monastery from plague. ${ }^{30}$ Similarly, Bede viewed Oswald as gifted with powers of exorcism: one of the miracles attributed to him in $H E$ is the curing of a demoniac using earth onto which water that had washed Oswald's bier had been poured. Here too Oswald is casting out the devil. ${ }^{31}$

The strength of Oswald's Christian faith is made clear for us by Bede at the end of Ch. 1 of Book III ("cum parvo exercitu, sed fide Christi munito") ${ }^{32}$ and even more clearly at the start of Ch. 2; indeed, Bede spends more time describing Oswald's spiritual preparation ahead of the battle than he allows to the fighting itself, which is given a bare quarter-sentence at the end of Ch. 1 ("the abominable leader of the Britons, together with the immense forces that he boasted nothing could resist, was destroyed in the place which in the language of the English is called Denisesburna, that is the brook of Denisus"). ${ }^{33}$ Heavenfield was Oswald's eve-of-battle camp rather than the battlefield itself: the fighting took place about seven miles to the south, on the Denisesburna. ${ }^{34}$ This was identified in the mid-19th century as the Rowley Burn, which lies a little to the south of Hexham, by Canon William Greenwell, on the basis of a charter issued by Thomas de Whittington for the archbishop of York in $1233 .{ }^{35}$ In Bede's account, Oswald's preparation consisted of raising "the sign of the cross" at Heavenfield and then encouraging his army to pray in front of it before

30 $\quad H E$ IV.14: in another parallel with $H E$ III.1-2 Bede creates another Oswald-Caedwalla apposition by making the central figure in $H E$ IV.15 the Caedwalla who was king of the West Saxons.

HE III.11; for discussion of the role of the devil in this story, see Peter Dendle, Satan Unbound: the Devil in Old English Narrative Literature (Toronto, 2001), pp. 94-95.

32 "[W]ith a small army, but strengthened in the faith of Christ."

33 "[I]nfandus Brettonum dux cum inmensis illis copiis, quibus nihil resistere posse iactabat, interemtus est in loco, qui lingua Anglorum Denisesburna, id est rivus Denisi, vocatur" (Colgrave and Mynors, p. 214; I have altered their translation slightly here).

34 Welsh sources (Historia Brittonum and Annales Cambriae) identify the site of the battle as Cantscaul, probably a Welsh rendering of the name Hexham: Kenneth Jackson, "On the Northern British Section in Nennius," in Studies in the Early British Border, ed. Nora Chadwick (Cambridge, 1963), p. 34; Andrew Breeze, "Bede's Hefenfeld and the Campaign of 633," Northern History 44 (2007), 193-97.

35 William Greenwell, "Address to the Members of the Tyneside Naturalists' Field Club (read 19 March 1863)," Transactions of the Tyneside Naturalists' Field Club 6 (1863-64), 1-33 at 13-14. 
moving off to fight the enemy as dawn broke. This account has until fairly recently been accepted by scholars as historically believable evidence for the raising of a free-standing cross and has often been taken as the starting point for the introduction of free-standing monumental crosses into Northumbria. ${ }^{36}$ More recently, this interpretation has been called into question by archaeologists, art historians and historians who view the introduction of monumental crosses into Northumbria as a development unlikely to have begun before the later 7 th century at the earliest. Moreover, Bernicia was not the earliest part of Northumbria to develop monumental crosses, a form of art which seems to have been pioneered by Whitby in Deira. ${ }^{37}$ Oswald's own lifetime was a decisive period for the cult of the Cross: in 630 the True Cross, which had been removed from Jerusalem by the Persians in 614 , was brought back to Jerusalem and then in 636 taken to Constantinople; ${ }^{38}$ the Feast of the Invention of the Cross was developed in the first half of the 7 th century at Rome, with a prayer about the Cross being inserted into a sacramentary under 14 September in the first quarter of the century and a full mass for the feast being composed probably under Pope Honorius I $\left(625^{-38)}\right)^{39}$ It is unlikely, however, that Oswald himself would have been aware of much if any of this, and more probable that the cult of the Cross became popular in Anglo-Saxon England after the middle of the century. Several modern scholars are thus unwilling to accept a freestanding cross, even a wooden one, at Heavenfield as early as the 630 (though clearly one existed in Bede's own day, a point to which we will return):40 as a result, the symbolic elements in Bede's narrative (whose significance has long been recognised) have come further into the foreground of discussion.

36 See for example Blair, The World of Bede, p. 102; Paul Meyvaert, "A New Perspective on the Ruthwell Cross: ecclesia and vita monastica," in The Ruthwell Cross, ed. Brendan Cassidy (Princeton NJ, 1992), pp. 95-166, at p. 106; Richard N. Bailey, England's Earliest Sculptors (Toronto, 1996), pp. 47-48, though he goes on (p. 50) to propose "that the Oswald cult, and particularly the cross associations of that cult, was a relatively late development."

Rosemary Cramp, "A Reconsideration of the Monastic Site of Whitby," in The Age of Migrating Ideas. Early Medieval Art in Northern Britain and Ireland, ed. R.M. Spearman and John Higgitt (Edinburgh, 1993), pp. 64-73, esp. p. 70; see also Elizabeth Coatsworth, "The Cross in the West Riding of Yorkshire," in The Place of the Cross in Anglo-Saxon England, ed. Catherine E. Karkov, Sarah Larratt Keefer and Karen Louise Jolly (Woodbridge, 2006), p. 18.

38 Ian Wood, "Constantinian Crosses in Northumbria," in The Place of the Cross in AngloSaxon England, ed. Karkov, Keefer and Jolly, pp. 3-13, at p. 7 .

39 Éamonn Ó Carragáin, Ritual and the Rood: Liturgical Images and the Old English Poems in the Dream of the Rood Tradition (London, 2005), p. 190.

40 Orton, Wood and Lees, Fragments of History: Rethinking the Ruthwell and Bewcastle Monuments, pp. 171-72; Wood, "Constantinian Crosses"; Coatsworth, "The Cross in the West Riding of Yorkshire." 
In recounting the story of Oswald raising a cross at Heavenfield Bede was influenced by ideas surrounding the cult of the Cross from his own day. Éamonn Ó Carragáin has pointed out that Bede, in putting the words "Flectamus omnes genua" ("Let us all bend our knees") into Oswald's mouth, was making the king cite the opening words of the solemn Good Friday prayers that were developed in Rome (where they were associated with the veneration of a cross) at the end of the $7^{\text {th }}$ century. ${ }^{41}$ Several scholars have noted the conscious parallel Bede is making in his account with Rufinus' account (in his version of Eusebius' History) of Constantine's vision of the cross at the Milvian Bridge, though they have also noted that the parallel is not exact, since Oswald, unlike Constantine, was not a convert, while, as Ian Wood notes, Jerome's story of Constantine's association with Arianism made the emperor a questionable role-model. ${ }^{42}$ However, Bede must have wanted to suggest that Oswald emulated Constantine in bringing Christianity to his people. Bede's own community shared in the developing cult of the Cross in the early 8th century; Abbot Hwaetberht (in office $716-c .750$ ), was the author of a Latin riddle entitled "De cruce," and a cross-slab of the late 7th or early 8th century survives at Jarrow with the inscription "In hoc singulari [sig]no vita redditur mundo" (in this unique sign life is restored to the world"), taken from the titulus of a statue of Constantine quoted in Rufinus' version of Eusebius' Ecclesiastical History. ${ }^{43}$ Its reference to the cross as a sign is echoed in Bede's account of Heavenfield in HE III.2.

Nonetheless, there was a real wooden cross on the site at the time Bede was writing: he informs us that he received his information about Heavenfield from members of the community of the church of Hexham (founded in or just after

41 Ó Carragáin, Ritual and the Rood, pp. 231-32; Éamonn Ó Carragáin, "Sources or Analogues? Using Liturgical Evidence to Date The Dream of the Rood," in Cross and Cruciform in the Anglo-Saxon World: Studies to Honor the Memory of Timothy Reuter, ed. Sarah Larratt Keefer, Karen Louise Jolly and Catherine E. Karkov (Morgantown, VA, 2010), pp. 152-53. See also Orton, Wood and Lees, Fragments of History: Rethinking the Ruthwell and Bewcastle Monuments, pp. 170-80, and Paul J. Stapleton, 'The Cross Cult, King Oswald, and Elizabethan Historiography', British Catholic History 33 (2016), 32-57, at pp. 35-37.

42 Wallace-Hadrill, Bede's Ecclesiastical History, p. 89; Wood, "Constantinian Crosses," pp. 4-6; the Constantinian parallels had also been noted by Peter Hunter Blair, but he thought Oswald actually did raise a cross at Heavenfield (cf. Peter Hunter Blair, Northumbria in the Days of Bede (London, 1976), p. 140); see also Jennifer O'Reilly, "Reading the Scriptures in the Life of Columba," in Studies in the Cult of St Columba, ed. Cormac Bourke (Dublin, 1997), pp. 80-106, at pp. 81-82.

43 Rosemary Cramp, Corpus of Anglo-Saxon Stone Sculpture, I: County Durham and Northumberland, 2 vols (Oxford, 1984), 1:112-13 (Jarrow 16a-b); Bailey, England's Earliest Sculptors, p. 49; Ó Carragáin, Ritual and the Rood, p. 32. 
$671 / 3$ ) and he is unlikely to have stated something that they might contradict.44 The brethren of the church of Hexham were developing Heavenfield as an Oswald cult site probably already at the time of Wilfrid, founder of their church, and more strongly under Bishop Acca. ${ }^{45}$ Bede says that not only had they for a long time ("multo iam tempore") maintained the practice of visiting the place on the eve of Oswald's feast day (4 August; Oswald's death at Maserfelth had occurred on 5 August 642), but they had recently ("nuper") built a church there to make the place more sacred (Éamonn Ó Carragáin notes that the church was presumably built after Acca had become bishop in 709). ${ }^{46}$ By Bede's time, there was a wooden cross of some age on the site; it was frequently chipped away at by local inhabitants to supply splinters of wood to be immersed in water for medicinal purposes for both humans and livestock, and was old enough to have "old moss" ("de veteri musco") growing on it that supplied medication for a contemporary of Bede's, Bothelm, a brother of the Hexham community, who had broken his arm after slipping on some ice. ${ }^{47}$ For the cross to have been old enough to have old moss growing on it by 731 would not, however, mean that it had to be any older than the end of the 7 th century: indeed if a wooden cross had by any chance been raised at Heavenfield in 634 it would probably have rotted well before 731 . It is possible therefore that the cross had originally been set up by the community of Hexham in the later 7 th century to provide a focus for the cult of Oswald at Heavenfield. For Bede, however, the cross was Oswald's own work and he was keen to explore the full range of symbolism that this interpretation offered.

Before we turn to Bede's use of Gospel symbolism in this passage we need to compare his account of Oswald's activities before the battle with that provided

44 For the name Hexham, see Donald Bullough, "The Place-Name Hexham and its Interpretation," Notes and Queries 46 (1999), 422-27, correcting Victor Watts, "The Place-Name Hexham: A Mainly Philological Approach," Nomina 17 (1994), 119-36; on Wilfrid's foundation of the church of Hexham see Wilfrid: Abbot, Bishop, Saint: Papers from the 13ooth Anniversary Conferences, ed. N.J. Higham (Donington, 2013).

45 Alan Thacker, "Membra Disjecta: The Division of the Body and the Diffusion of the Cult," in Oswald: Northumbrian King to European Saint, ed. Stancliffe and Cambridge, pp. 97127, at pp. 110-11, suggests that the community of Hexham started to develop Heavenfield as an Oswald cult site under Wilfrid, but that "Oswald's most enthusiastic sponsor" was Bishop Acca (deposed 731). See Bailey, England's Earliest Sculptors, p. 50, and more generally D.P. Kirby, "Northumbria in the Time of Wilfrid," in St Wilfrid at Hexham, ed. D.P. Kirby (Newcastle upon Tyne, 1974), pp. 26-27.

46 HE III.2; Ó Carragáin, Ritual and the Rood, p. 232.

47 HE III.2. 
by Adomnán in his Life of Columba..$^{48}$ Adomnán supplies an account which, he says, he had been told by his predecessor, Abbot Failbe, who had himself been told it when young by Oswald as the latter stated it to Abbot Segene. ${ }^{49}$ Unlike Bede's account, which was third- or fourth-hand at best, Adomnán's was second-hand and much closer to Oswald. He, too, however, wanted to shape his material and he tells the story to give an example of how God honoured Columba with the gift of prophecy. Oswald, encamped ("castrametatus") and ready for battle against Caedwalla ("Cathlonem Britonum regem fortissimum"), had a vision of St Columba as he slept. The saint was so tall that he touched the clouds; spreading out his shining garment to cover almost all of Oswald's camp he comforted Oswald with a version of the words with which God had comforted Joshua on the death of Moses: "Be strong and act manfully. Behold, I will be with thee" (cf. Joshua 1:9). After this Columba told Oswald to set off to fight the following night and said that his enemies would flee, that Caedwalla would be delivered into his hands and that Oswald would be victorious and would reign happily..$^{50}$ When he woke up Oswald explained the vision to his advisers and they promised that they would seek baptism after the battle; Adomnán here explains that "all Saxony," that is, all the Angles, were pagan at this point save Oswald and twelve followers who had been with him in exile among the Irish. ${ }^{51}$ By contrast, Bede's account makes no mention of Columba, and he presents Oswald's soldiers as ready to pray in front of Oswald's cross, in other words already Christian converts. The difference between Adomnán's account and Bede's is so great that it has led some commentators to assume that Bede could not have read Adomnán's Life of Columba. ${ }^{22}$ This is the impression that Bede seems to wish the reader to form in $H E$ III.4, in which he remarks Columba's pupils are said to have written many things about his life and

48 O'Reilly, "Reading the Scriptures," pp. 81-85, compares Bede's and Adomnan's accounts of Heavenfield.

49 Adomnan's Life of Columba, ed. and trans. Anderson, p. 14.

5o Adomnan's Life of Columba, ed. and trans. Anderson, p. 14.

$5^{1}$ There may be a possible link here with Bede's mention of Eanfrith having only twelve companions when he met Caedwalla (HE III.1), though in both cases the biblical symbolism is the important factor (O'Reilly, "Reading the Scriptures," pp. 82-83, notes the link between Oswald's twelve Christian followers and the twelve men who set up twelve stones at the command of Joshua in Joshua 4:2-3).

52 E.g. Colgrave and Mynors, p. 225 n. 2: "Bede does not appear to have known the Life of Columba written by Adamnan." For the transmission of the Life of Columba see Adomnan's Life of Columba, ed. and trans. Anderson, pp. liv-lxv and Adomnán, Life of St Colum$b a$, trans. Sharpe, pp. 88-89: there is no specific evidence for early circulation of the work in Anglo-Saxon England but certainly this possibility cannot be excluded. 
words. ${ }^{53}$ However, it has been suggested that he did know these but was unwilling to cite them directly. ${ }^{54}$ As Richard Sharpe observes, Bede was anxious to present the Heavenfield story differently from Adomnán: he had to depict the Anglo-Saxon Bernicians as Christian at this point to avoid portraying the battle as a "victory of pagan English over Christian Britons," which "would go right against the theme of his work." 55 It is also worth noting that this depiction of Christian Bernician Angles accords oddly with Bede's curious insistence in $H E$ III.2 that there were no churches or altars in Bernicia until after Oswald's victory (a statement that is in itself odd given his comments about Paulinus' missionary activity in Bernicia in $H E$ II.14). ${ }^{56}$ Bede's divergence from Adomnán's account is very similar to the divergence visible between his description of Edwin's conversion and that presented in the Whitby Life of St Gregory, especially the presentation of the visionary figure appearing to Edwin while he was in exile. ${ }^{57}$ In both cases it is possible that what Bede is doing is consciously altering an existing narrative rather than being ignorant of it. Moreover, he was strongly interested in Adomnán, whose work on the Holy Places he quotes in Book v, with approval, and he thought highly of the latter's attempt (albeit unsuccessful) to introduce Roman Easter dating to Iona. ${ }^{58}$

Bede's decision to pass over in silence Oswald's own account of seeing a vision of Columba at Heavenfield meant that he was able to show Oswald placing his faith firmly in Christ crucified, with no mediation through a saint, much less one, like Columba, who dated Easter incorrectly. ${ }^{59}$ Here a further Gospel allusion comes into play. Shortly after Christ's statement about how a stronger man will despoil the strong man armed comes his condemnation of the wicked generation seeking a sign to believe in and his remark that they will receive no sign but the one of the prophet Jonah, whose three nights in the belly of the whale foretell the three days spent by the Son of Man in the bowels of the earth (Luke 11:29-32; Matthew 12:38-42). In his commentary on Luke 11:29 Bede

53 Plummer (2:135) points out that Bede's "de cuius vita et verbis nonnulla a discipulis eius feruntur scripta haberi" ( $H E$ III.4) implies that Bede himself did not have access to them. "Indeed, Bede's Constantinian version of events could imply a definite rejection of the Ionan model": Wood, “Constantinian Crosses," p. 4.

55 Adomnán, Life of St Columba, trans. Sharpe, p. 252.

56 As noted by, for example, Peter Hunter Blair, The World of Bede (London, 1970), p. 102.

57 See discussion by Julia Barrow, "How Coifi pierced Christ's side: A Re-examination of Bede's Ecclesiastical History, II, Chapter 13," Journal of Ecclesiastical History 62 (2011), 693706, at pp. 697-700, 706 .

$5^{8} \quad H E$ V.15-17 (Holy Places) and v.15 for Easter dating. See also $H E$ IV.25, with discussion by Julia Barrow, "Bede's Wise and Foolish Virgins," forthcoming, for Bede's favourable description of Adomnán's namesake.

HE III.4. 
pointed out that the wicked generation would receive only a sign of Christ's incarnation and passion, not his divinity or his glorification, whereas Christ's disciples were shown his transfiguration on the mountain and his ascension into heaven. This explains why it is a cross, or more particularly "the sign of the cross," that Oswald erected at Heavenfield in Bede's account: the Bernician Angles are receiving the sign of Christ's passion. ${ }^{60}$ Again, the parallels between Oswald and Christ are being drawn out, with the reader being encouraged to think ahead to Oswald's eventual death in battle at the hands of Penda's forces. ${ }^{61}$

In particular, it was the name of the site, Heavenfield, which inspired Bede:

This place is called in English Heavenfield, and in Latin Caelestis campus, a name which it certainly received in days of old as an omen of future happenings; it signified that a heavenly trophy was to be erected there, a heavenly victory begun, and that heavenly miracles were to take place there continuing to this day. ${ }^{62}$

Bede's remark that the victory was merely "begun" in 634 implies that it needed to be completed, or won, evidently by Oswald's martyrdom in 642. His sentence is rich in military metaphors used for spiritual concepts ('trophy', 'victory' and indeed 'field' itself): these receive extra emphasis from the repeated use of the adjective caelestis, heavenly. The term 'trophaeum' barely occurs in the Vulgate (only in 2 Maccabees 5:6 and 15:6), but was used, along with the word triumphus, by Evagrius in his Latin translation of Athanasius' Life of Anthony to emphasise the triumph of Christ. ${ }^{63}$ This was a work that Bede knew well, as it

6o "Et accepit et dedit signum videlicet incarnationis non divinitatis passionis non glorificationis. Discipulis autem suis signum de caelo dedit quibus aeternae beatitudinis gloriam et prius figuraliter in monte transformatus et post veraciter in caelum sublevatus ostendit" (In Lucae evangelium exposition, p. 238 (IV.xi.29)), See also n. 43 above.

61 Oswald's death at the hands of the Mercians at Maserfelth is recounted by Bede in $H E$ III.9.

62 'Vocatur locus ille lingua Anglorum Hefenfeld, quod dici potest Latine 'Caelestis Campus', quod certo utique praesagio futurorum antiquitus nomen accepit: significans nimirum quod ibidem caeleste erigendum tropeum, caelestis inchoanda uictoria, caelestia usque hodie forent miracula celebranda." Colgrave and Mynors, pp. 216-17 (HE III.2), with adaptations to their translation ('trophy' for 'sign', and 'begun' for 'won'). Breeze, 'Bede's Hefenfeld," pp. 196-97 suggests that Caelestis in Caelestis Campus is a personal name in the genitive ("the field of Caelestis").

63 G.J.M. Bartelink, "Grécismes lexicologiques et syntaxiques dans les traductions latines du IVe siècle de la Vita Antonii d'Athanase," Mnemosyne 30 (1977), 388-422, at pp. 403-04. 
was one of the models for his prose Life of Cuthbert. ${ }^{64}$ Bede uses 'tropheum' of Christ's passion in his commentary on Luke, 8:37: "The trophy of his (Christ's) passion and the glory of his resurrection will be made known to the tribes of Judaea that they should believe." 65 There may be a conscious contrast here between Oswald's Christian trophy and the thufborne before the virtuous but (in Bede's eyes) less holy Edwin as he processed around his kingdom in $H E$ II.16.

In conclusion, it seems not impossible that Bede had read Adomnán's Life of Columba, but rejected its story of how Oswald was inspired by a vision of Columba at Heavenfield. Instead, Bede (presumably following the view of the community at Hexham) chose to interpret the cross at Heavenfield as an artefact placed there at Oswald's command. But the starting point of the whole narration was probably Bede's reflection on the division of Northumbria at Edwin's death and the close parallels this supplied with the parables of the divided kingdom and the strong man armed in Luke and Matthew, allowing him to present Osric and Eanfrith as open to demoniac possession through their loss of faith, Caedwalla as a mirror-image of Satan and Oswald as a Christ-like figure who was able to take on Satan and free the divided kingdom or house from attack. Since in both gospels these parables are followed by the statement that the current generation would receive no sign other than the sign of Jonah (usually interpreted, for example by Bede himself, as Christ's Passion), this allowed Bede to build up to his narrative of Oswald raising up a cross at Heavenfield and leading his followers in a Good Friday prayer, thus further underlining Oswald's saintly qualities and marking him out as the only truly holy Northumbrian king.

64 Two Lives of St Cuthbert, ed. and trans. Bertram Colgrave (Cambridge, 1940), p. 16 and see also pp. 11-13.

65 In Lucae evangelium expositio, p. 187 (III.viii.37): "Cuius tamen tropheum passionis resurrectionisque Gloria credituris Iudaeae tribubus intimabitur." 